\title{
三軸分光器入門
}

益田 隆嗣

（東京大学 物性研究所 中性子科学研究施設）

\section{Introductory Lecture on Triple-axis Spectrometer}

Takatsugu Masuda

Neutron Science Laboratory, ISSP, the University of Tokyo

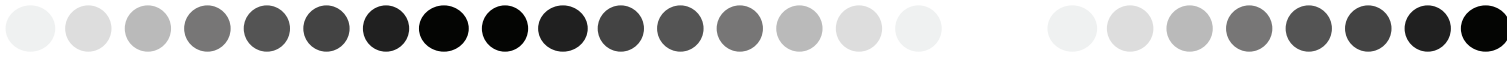

\begin{abstract}
Triple-axis spectrometer is a multi-purpose instrument for powder neutron diffraction, single crystal neutron diffraction, powder inelastic neutron scattering, single crystal inelastic neutron scattering, and neutron polarization analysis. In this lecture how to use the triple-axis spectrometer is explained for the beginners.

Keywords: Triple-axis spectrometer
\end{abstract}

\section{1.はじめに}

三軸分光器は, 主として磁性 - 強相関分野の研 究ツールとして精力的に利用されている。一番の 特徵は, 波数-エネルギー空間の任意の点で中性子 動的構造因子を測定できる点にあり, 非弾性散乱 実験によるダイナミクス測定に大きな威力を発揮 している。一方で, 汎用性の高さも特徴の一つで あり,幅広い分野のユーザーに有用な弾性散乱(回 折実験）でも数多くの成果が挙げられている. 最 近の中性子集光・試料環境技術の進歩により，薄 膜試料, パルス磁場環境, 小さな磁気モーメント を有する粉末試料，などの実験が可能となってお り，広い意味での物性物理，化学の分野の方々に 興味を持っていただける分光器にもなっている. ここ数年の研究例としては, $\mathrm{Fe}_{3} \mathrm{O}_{4} / \mathrm{CoO}$ 薄膜の交 換バイアス[1], パルスマグネットを用いた $30 \mathrm{~T}$ 高 磁場下での磁気散乱[2], 多孔質ソーダライトに内 包された $\mathrm{Na}$ 磁性の磁気構造[3], ヘキサフェライ 卜の複雑な磁気構造[4,5]などが挙げられる。本稿 では, 三軸分光器の未経験者に当該分光器に興味 を持っていただくことを目的とし，その原理と使 用方法を簡潔に説明する.

\section{2. 三軸分光器で何が測定できるか?}

三軸分光器は汎用性の高い分光器であり, 粉末 中性子弾性散乱, 単結晶中性子弾性散乱, 粉末中 性子非弹性散乱, 単結晶中性子非弾性散乱を行う ことができる，さらに，中性子偏極子を装備した 分光器では, 中性子偏極解析も可能である. 中性 子実験は事前に測定内容を吟味して行うことが普 通であるが，三軸分光器においては，実験期間中
の計画変更にフレキシブルに対応することが可能 である。たとえば，主目的の単結晶試料の他にバ ックアップ実験の粉末試料を用意しておけば，主 実験の試料環境調整の合間に，粉末試料の磁気回 折についての予備的な結果を得ることが出来る.

汎用性の高さは, 三軸分光器がきわめてシンプル な原理に基づいており, ユーザーが分光器のコア な部分に容易にアクセス寸ることが可能であるこ とに起因する，そこで本節では，三軸分光器の原 理を説明する.

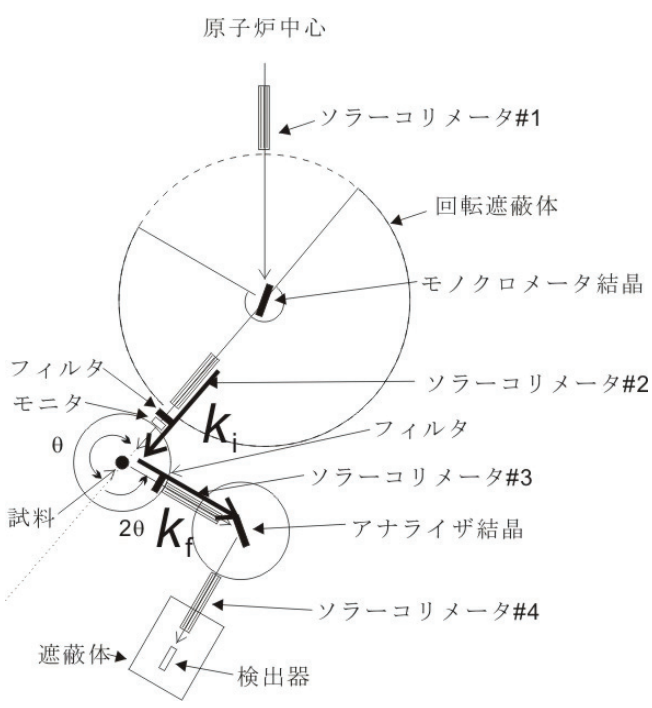

Fig.1 Schematic view of triple-axis spectrometer. 
Fig. 1 に三軸分光器の概念図を示す. 原子炉中心 でウラン燃料の核分裂により発生した中性子は, モノクロメータ結晶, 試料, アナライザ結晶に散 乱されて検出器に到達する. オークリッジ国立研 の三軸分光器 HB-1 の実物を Fig. 2 に示す. 試料

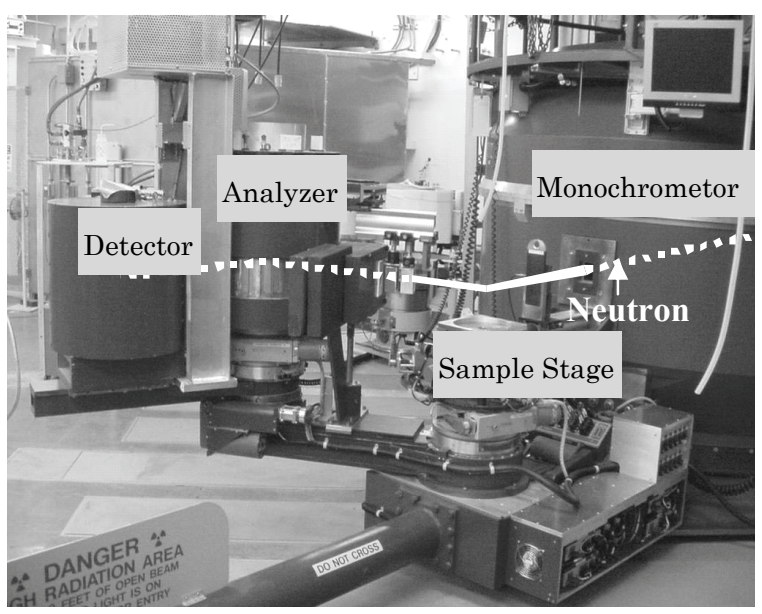

Fig.2 Triple-axis spectrometer HB-1 installed in Oak Ridge National Laboratory.

ステージには，試料回転の角度 $\theta$ ，散乱角 $2 \theta$ の 自由度がある。同様の自由度は，モノクロメータ 結晶とアナライザ結晶にもあり，試料を含めて 3 つの結晶が回転するので 3 軸分光器と呼ばれてい る.モノクロメータとアナライザ (Fig.3 (a))には, 多くの場合 Pyrolytic Graphite（PG）結晶と呼ばれ るものが用いられる. ソラーコリメータ（Fig. 3 (b),(c)）は，モノクロメータの前，試料の前後， 検出器の前の 4 か所に設置されており, 中性子ビ 一ムの発散角を抑える働きをする.試料の前には, 中性子をカウントするモニタが設置され，测定時 間を試料に照射する中性子数で規格化できるよう になっている。試料の前もしくは後ろには，フィ ルタ（Fig.3 (d)）が設置され, モノクロメータやア ナライザからの高調波の散乱をカットするローパ スフィルタの役割をしている。検出器では, ${ }^{3} \mathrm{He}+$ $\mathrm{n} \rightarrow{ }^{3} \mathrm{H}+\mathrm{p}$ の ${ }^{3} \mathrm{He}$ 原子の電離反応を利用した中 性子検出がなされている。実験者は，モノクロメ 一タとアナライザの結晶の種類, 結晶角度, コリ メータの発散角, フィルタの種類を調整すること

で，目的の研究に適した実験環境をコントロール することが出来る.

原子炉には複数の三軸分光器が設置されている が，熱中性子を利用するものと，冷中性子を利用 するものに大きく分けられる. 前者は $1.8 \AA$ にフラ ックスの極大を有しており，一般の弾性散乱実験 や $2 \mathrm{meV}$ 以上のエネルギースケールの素励起測定 に用いられる。後者は $4 \AA$ にフラックスの極大を 有しており, 磁性体の磁気ブラッグピークを, 角 度分解能を高くして測定したい場合や， $10 \mathrm{meV}$ 以 下の素励起測定に用いられる。前者はさらに，炉 室に設置されているものと, 実験ホールに設置さ れているものに分けられる。前者は，大きいビー
ム発散を利用することでフラックス強度が増すた め, 非弾性散乱実験や，微弱なピークを探査する 場合に有利である。後者は，中性子導管による中 性子輸送の際にビーム発散が抑えられるため，平 行性の高いビームが得られ，高角度分解能の実験 が可能である。どのタイプの分光器を選ぶかは, 実験前に決定しておかなければならない。JRR-3 には, Table 1 にあるような分光器群が設置されて いる. (a)

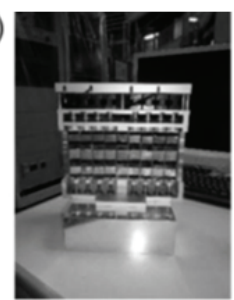

(c)

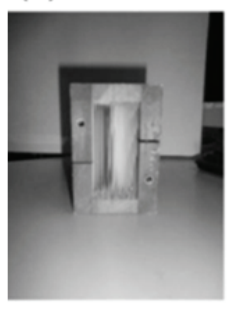

(d)

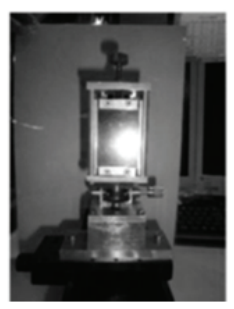

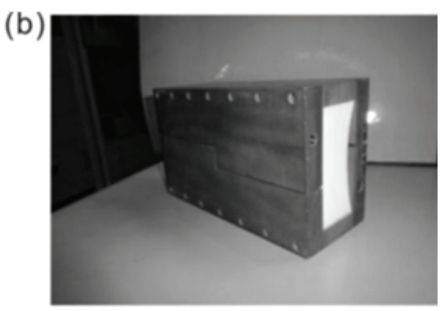

(e)

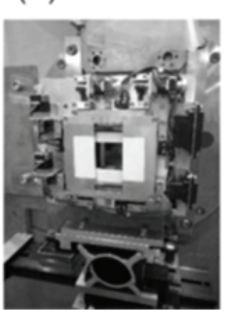

Fig. 3 (a) PG analyzer installed in ISSP 5G beam line. (b),(c) Soller collimator (d) PG filter (e) Beam narrower.

Table 1 Triple-axis spectrometers installed in JRR-3.

\begin{tabular}{|c|c|c|c|c|}
\hline ビーム孔 & $\begin{array}{l}\text { 装置 } \\
\text { 略称 }\end{array}$ & $\begin{array}{l}\text { 管理 } \\
\text { 組織 }\end{array}$ & $\begin{array}{l}\text { 装置 } \\
\text { 責任者 }\end{array}$ & 分類 \\
\hline $2 G$ & TAS-1 & $\begin{array}{l}\text { 原子力 } \\
\text { 機構 }\end{array}$ & $\begin{array}{l}\text { 脇本 } \\
\text { 武田 }\end{array}$ & $\begin{array}{l}\text { 熱中性子・ } \\
\text { 炉室・偏極 }\end{array}$ \\
\hline $4 \mathrm{G}$ & GPTAS & $\begin{array}{l}\text { 東大 } \\
\text { 物性研 }\end{array}$ & $\begin{array}{l}\text { 柴山 } \\
\text { 佐藤卓 }\end{array}$ & $\begin{array}{l}\text { 熱中性子・ } \\
\text { 炉室内 }\end{array}$ \\
\hline $5 \mathrm{G}$ & PONTA & $\begin{array}{l}\text { 東大 } \\
\text { 物性研 }\end{array}$ & $\begin{array}{l}\text { 益田 } \\
\end{array}$ & $\begin{array}{l}\text { 熱中性子 } \\
\text { 炉室・偏極 }\end{array}$ \\
\hline $6 \mathrm{G}$ & TOPAN & $\begin{array}{l}\text { 東北大 } \\
\text { 学理 }\end{array}$ & 岩佐 & $\begin{array}{l}\text { 熱中性子・ } \\
\text { 炉室 }\end{array}$ \\
\hline T1-1 & HQR & $\begin{array}{l}\text { 東大 } \\
\text { 物性研 }\end{array}$ & 吉沢 & $\begin{array}{l}\text { 熱中性子・ } \\
\text { 実験ホール }\end{array}$ \\
\hline T1-2 & AKANE & $\begin{array}{l}\text { 東北大 } \\
\text { 学金研 }\end{array}$ & 大山 & $\begin{array}{l}\text { 熱中性子・ } \\
\text { 実験ホール }\end{array}$ \\
\hline T2-4 & TAS2 & $\begin{array}{l}\text { 原子力 } \\
\text { 機構 }\end{array}$ & $\begin{array}{l}\text { 長壁 } \\
\text { 久保田 }\end{array}$ & $\begin{array}{l}\text { 熱中性子・ } \\
\text { 実験ホール }\end{array}$ \\
\hline C1-1 & HER & $\begin{array}{l}\text { 東大 } \\
\text { 物性研 }\end{array}$ & $\begin{array}{l}\text { 横山 } \\
\text { (茨大) }\end{array}$ & $\begin{array}{l}\text { 冷中性子・ } \\
\text { 実験ホール }\end{array}$ \\
\hline $\mathrm{C} 2-1$ & LTAS & $\begin{array}{l}\text { 原子力 } \\
\text { 機構 }\end{array}$ & $\begin{array}{l}\text { 金子 } \\
\text { 山内 }\end{array}$ & $\begin{array}{l}\text { 冷中性子・ } \\
\text { 実験ホール }\end{array}$ \\
\hline
\end{tabular}


3. 弾性散乱実験

本節では弾性散乱実験の具体的手順について述 ベる

\section{(1) 試料準備}

粉末試料の場合は，中性子照射により放射化し た粉末試料が飛散しないように，試料缶に密封す る。まず, 内径 $6 \mathrm{~mm}-10 \mathrm{~mm}$ 程度, 高さ $60 \mathrm{~mm}$ 程度 のバナジウム製円筒容器に試料を入れる。この円 筒容器を, さらに直径 $54 \mathrm{~mm}$ のアルミ缶[6]に入れ, インジウムワイヤにより完全に密閉する。試料ボ リュームは典型的には $1 \mathrm{cc} \sim 3 \mathrm{cc}$ 程度である。もし バナジウム容器の入手が困難な場合, 肉厚 $0.05 \mathrm{~mm}$ 程度のアルミ製円筒容器を用いても良い。試料ボ リュームが 3cc 程度あれば，肉薄アルミ製容器で も大きな問題はない.

単結晶試料の場合は，あらかじめ結晶軸を X 線 ラウエ写真撮影などにより同定し, 散乱面を水平 面とするように，試料を固定しておくことが望ま しい，試料ホルダ等の図面は物性研中性子施設ホ ームページ[6]などで入手可能である．ただし，通 常の X 線は結晶表面で散乱されるため, ラウエ写 真でラウエスポットが観測されても，必ずしも結 晶全体がシングルドメインになっている保証はな い.このため，X線で確認した試料であっても， 本測定の直前に必ず中性子で試料チェックを行う ことが必要である[7]. 試料ボリュームは $1 \mathrm{cc}$ 程度 あれば理想的であるが，多くの場合 $0.1 \mathrm{cc}$ 程度で も十分な実験が可能である。試料形状は球形に近 いものが理想的であるが，通常は直方体，平板状 試料を用い，解析の段階で吸収補正を行う.

\section{（2）中性子実験}

モノクロメータとアナライザで同じ波長の中性 子を選ぶか，あるいはアナライザ結晶を外して， 実験室系の粉末 X 線回折装置のようにして（二軸 モード）実験する。後者は正確な積分強度を得る ことが容易だが，バックグランドが高くなる．超 格子ピークのように弱いピークを測定したい場合 には，前者で測定する方が良い，熱中性子を $\mathrm{PG}$ モノクロメータで単色化する場合, 波長は, $\lambda=2.46$,

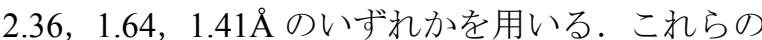
波長では, PG モノクロメータ結晶からの $\lambda / 2, \lambda / 3$ 高調波を PG フィルタが効率的に排除してくれる. コリメータは, 基本的には 20’や 40'程度の細かい ものを選び，角度分解能を高めるのが良い。二軸 モードの場合，第 4 コリメータは外寸。試料サイ ズが小さい場合や測定時間が限られている場合に は，コリメータ発散角を広いものを用いる。制御 ソフトは, 施設, 分光器により様々なものが使用 されているが，実験に必要なコマンドは限定的で あり，慣れるのに時間はかからない，粉末試料の 実験であれば，試料の散乱角 $2 \theta$ を動かすだけで ある。単結晶の場合，最初に 2 つの独立な結晶面 のブラッグピークを探す.それらの $\theta, 2 \theta$ 情報を

$(h k l)$ 指数と結晶格子情報とともに制御コンピュ
一タに入力することで， $\theta, 2 \theta$ と $(h k l)$ 指数が 対応付けられる。後は, 目指寸 $(h \mathrm{kl})$ に移動し, その周りで $\theta$ スキャンと $\theta-2 \theta$ スキャンを実行す ればよい。測定可能な $(h k l)$ 領域がどの程度であ るかは，事前にシミュレーションしておくことが 望ましい. 後述の Virspec は便利なシミュレータ である。

三軸分光器の場合, 一つの散乱面内でのデータ 収集は可能であるが，散乱面外のデータを幅広く 測定することはできないことが多い.したがって, 全く新しい物質の結晶構造を決定することは困難 である。一方，既知の物質の超格子構造，磁気構 造を決定することは可能である。

試料前後には，ビームナロワー（Fig. 3(e)）を設 置する場合がある．中性子ビームの幅と高さを調 整することが可能なスリットであり，試料にあた るビームサイズを絞ることで，バックグラウンド を減らすことができる。

\section{(3) データ解析}

Rietveld 解析による構造解析ソフトがフリーウ ェアで配布されている[8]. 磁気構造に関しては, 対称性から可能な磁気モデルをリストアップして くれるソフトがフリーウェアで配布されている [9]. 構造解析ソフトと併用寸ることで, 磁気構造 解析が楽に行えるようになっている。

\section{4. 非弾性散乱実験}

\section{(1) 試料準備}

非弾性散乱強度は弾性散乱強度よりも2 桁以上 小さくなるので，基本的には，試料ボリュームは 多ければ多いほど良い。試料台中心での中性子ビ 一ムは，使用コリメータなどにより異なるが，最 大幅 $40 \mathrm{~mm}$ 高さ $40 \mathrm{~mm}$ 程度である．筆者は，粉末 試料の場合, 内径 $2 \mathrm{~cm}$ の円筒容器に高さ $5 \mathrm{~cm}$ 程度 に試料を詰めて実験を行うことが多い，容器はイ ンジウムシールで密封する，含まれている元素の 非干渉性散乱断面積や吸収断面積[10]が大きい場 合には，試料の厚みが大きいと，中性子が透過せ ず効果的な実験が出来ない場合がある。この場合 は，アルミ二重管容器のリング状のスペースに試 料を充填する。これにより，試料を通過する中性 (a)

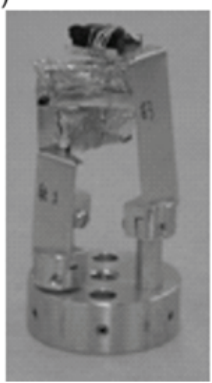

(b)

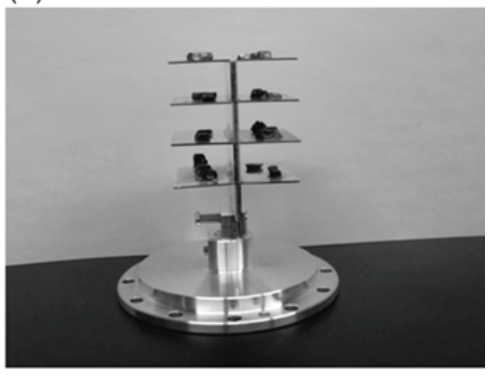

Fig. 4 (a) Three pieces of single crystals coaligned on sample holder. (b) 24 pieces of single crystals coaligned on sample holder. 
子経路の距離を減じることができ, 中性子透過率 の減少を抑えることができる。試料ボリュームを 稼げない場合には，試料に含まれる元素の散乱断 面積, 吸収断面積を考慮して効果的な試料容器の 設計を行う。あらかじめ粉末非弾性散乱実験のみ を行うことがはっきりと分かっている場合は，縦 $4 \mathrm{~cm}$ 幅 $4 \mathrm{~cm}$ 厚み $1-3 \mathrm{~mm}$ 程度のアルミ䇴で作製し た袋に粉末試料を入れ，これを押し固める.さら にカドミウム板で枠を作製し，試料の型崩れを防 ぐ、これをアルミ缶に固定する。測定時には，中 性子ビームが板状試料に垂直にあたるようにする。 単結晶試料の場合には, ビームサイズ程度の結 晶を得ることは困難である場合が多い.このため, 複数の結晶を, 軸を揃えて並べたものを用いる. 基本的には, 以下の作業を, 中性子を用いて行う。

1. 各結晶の独立なブラッグピークを二つ探し, 散 乱面が水平になるように試料ホルダに固定する.

2. 二つの結晶の軸が揃うように試料を並べて, ブ ラッグピーク周りでのロッキングカーブを測定す る. 3. 各結晶からのブラッグピークが 1 度程度の 誤差で重なるように調整する．4.3 つ目以降の結 晶についても2.と 3. の作業を行う。結晶を 3 つ並 ベた例と 24 個並べた例を Fig. 4 に示す. 実験ホー ル T11 ポートの HQR 分光器下流に設置された, 軸立て専用分光器は, マシンタイムを申請せずに 利用可能であるので, 結晶を並べる作業に用いる とよい、また，筆者の研究室は，高エネルギーX 線を利用した透過ラウエ写真装置を共同利用に提 供しているので，ご活用いただければと思う。結 晶形状から結晶軸が判断できる場合は, 中性子や X線を用いずに, 目で見て並べてもよい.ただし, 軸が揃っていることの確認は, 中性子か X 線を用 いて必ず行う. 1.5 度以内に揃っていれば本測定に 用いてよい.

\section{（2）中性子実験}

非弾性実験は，入射中性子エネルギー $\left(E_{i}\right)$ を 固定する場合と, 反射中性子エネルギー $\left(E_{f}\right)$ を 固定する場合の二つの方式に分けられる。 $E_{f}$ 固定 での実験の方がより一般的である。熱中性子を利 用する場合には， $E_{f}=13.5,14.7,30.5,41 \mathrm{meV}$ (波 長にすると $\lambda=2.46,2.36,1.64,1.41 \AA ）$ のいずれ かを用い, PG フィルタを第 3 コリメータの上流 に設置する.モノクロメータの $\theta, 2 \theta$, 試料の $\theta$, $2 \theta$, アナライザの $\theta, 2 \theta$ ，にはそれぞれ駆動可 能範囲が限定されているので, 目的とする $(h, k$, $1, \hbar \omega)$ が測定可能範囲に入るような分光器を選び, 実験条件を定めなければならない.

コリメータは，強度を稼ぐためになるべく発散 角の広いものを用いる. 三軸分光器の実験分解能 は, Cooper と Nathans により議論され[11], 現在 では便利なプログラムが公開されている[6]. 実験 条件を決定する上で, 分解能の選定は重要である. 分解能を上げれば高精度の実験を目指すことがで きるが, 強度が減少するため, 目的のシグナルを 観測するのに最低限必要な実験分解能となるよう
に条件を設定することが重要である，Zheludev 氏 のホームページで公開されている Virspec[12]は, 分解能関数シミュレータとして非常に使いやすい ので，簡単に説明しておく.

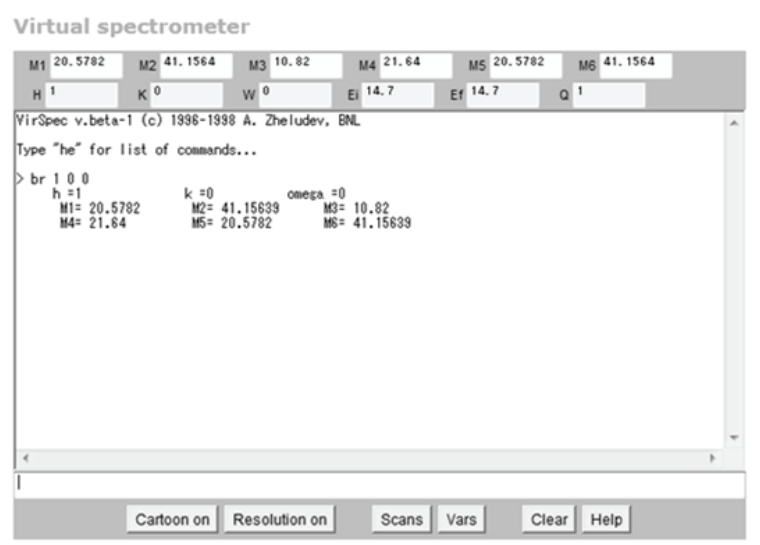

Fig. 5 Simulation program Virspec.

Virspec のページは Fig. 5 のようになっている. メニューは下にあり,「Vars」メニューで, 試料結 晶情報, モノクロメータ・アナライザ結晶面の種 類, コリメータ条件, $E_{i}, E_{f}$ などの実験条件を設 定する. 次に，ためしにコマンドラインで「br 10 $0 」$ と打ち込んでみる.これは, $h=1, k=0, \hbar \omega=0 \mathrm{meV}$ の場所に分光器を動かしなさい, というコマンド である.メインウィンドウ内に，モノクロメータ の $\theta, 2 \theta$, 試料の $\theta, 2 \theta$, アナライザの $\theta, 2$ $\theta$, 角度が, M1 M6 の值として表示される. 次 に, メニューの「Resolution on」をクリックする と, Fig. 6 が現れる.

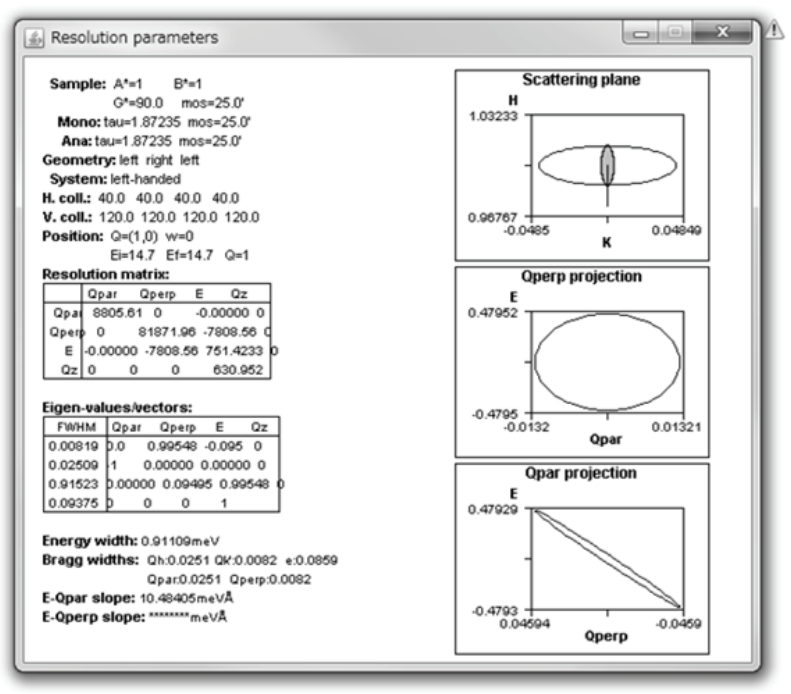

Fig. 6 Resolution parameters in Virspec.

左下の「Energy width」がエネルギー分解能であ る. 波数の分解能を散乱面に投影したものが右上 図に描かれており，異方的であることが分かる。 $\operatorname{Var}$ メニューでコリメータ条件, $E_{i}, E_{f}$ などを調整 してシミュレーションを行い, 最も適した実験条 件を探す．初めての測定で必要分解能が分からな 
い場合は，コリメーション発散角は最大, 熱中性 子の場合は $E_{f}=14.7 \mathrm{meV}$ 固定, 冷中性子では $E_{f}$ $=5 \mathrm{meV}$ 固定で実験することを推奨する.

単結晶での非弾性散乱実験を行う場合, 分解能 関数によるフォーカス効果を知っておくべきであ る。観測される中性子散乱強度は，

$$
\begin{aligned}
& I_{\text {obs }}\left(Q_{0}\right)=\int d Q R_{0}\left(Q_{0}\right) S_{\text {calc }}(Q) \\
& \times \exp \left[-\frac{1}{2}\left(Q^{i}-Q_{0}^{i}\right)\left(Q^{j}-Q_{0}^{j}\right) M_{i j}\left(Q_{0}\right)\right]
\end{aligned}
$$

$Q=\left(\hbar \omega, Q_{x}, Q_{y}, Q_{z}\right)$

で表される。 $S_{\text {calc }}(Q)$ は中性子動的散乱因子, $Q_{0}=k_{i}-k_{f}$ は散乱べクトル， $\hbar \omega$ はエネルギートラン スファー, $\mathrm{M}_{\mathrm{ij}}$ は分解能行列である. (1)式の被積 分関数を, 波数-エネルギー空間に投影すると, Fig. 7 のようになる. 図中では, 分解能関数とともに, $Q_{x}$ 方向に $30 \mathrm{meV}$ のエネルギーバンドと $3 \mathrm{meV}$ の エネルギーギャップを有する一次元分散曲線が描 かれている. 分解能関数は, 傾いた楕円の形をし ている. $Q_{x}=3.1$ では楕円の長軸の傾きが分散曲線 の接線と平行に近いため, 分解能はよくなるが, $Q_{x}=2.9$ ではほぼ直角になるため分解能は悪くなる. $\mathrm{S}(\mathrm{q}, \omega)$ は $Q_{x}=3$ について対称であるが, $Q_{x}<3$ では 分解能関数が off focus となり観測されるピークは ぼやけ, $Q_{x}>3$ では on focus となりピークは鋭くな る。良いデータを収集するためには，on focus 側 で一連のスキャンをすることが重要である.

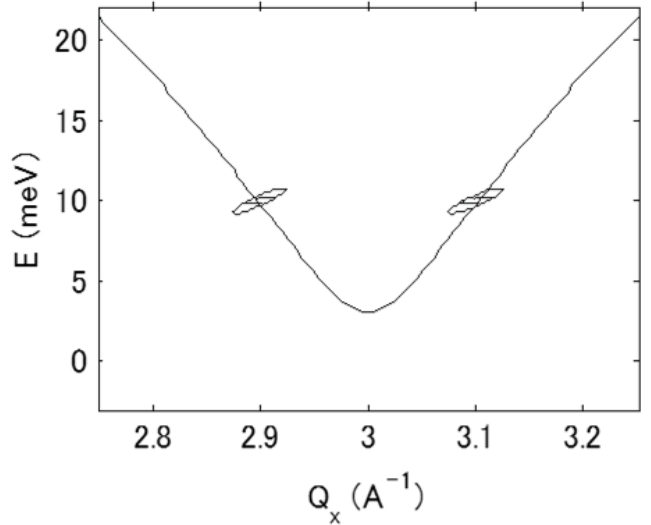

Fig. 7 Resolution functions (ellipsoid shape) projected onto $\mathrm{E}-Q_{x}$ plane. Solid Curve is a dispersion with energy gap of $3 \mathrm{meV}$ at $Q_{x}=0$.

測定中に偽のピークを観測するケースがしばし ば発生する．有名な例として, $E_{f}=14.7 \mathrm{meV}$ 固定 の条件下で $18.4 \mathrm{meV}$ に観測されるピークがある. 原因は，モノクロメータの $\lambda / 2$ 高調波が，試料の 非干渉性弾性散乱により散乱され，これをアナラ イザで $\lambda / 3$ 高調波として拾ってしまうことにある. 非干渉性散乱[10]の強い元素を含む試料を用いる 場合に顕著である。モノクロメータとアナライザ
の高調波の次数を各々 $\mathrm{n}_{\mathrm{M}}, \mathrm{n}_{\mathrm{A}}$ とすると, 試料の非 干渉性弾性散乱で高調波を拾ってしまうケースは, 一般に

$$
\left(n_{\mathrm{M}} k_{i}\right)^{2}=\left(n_{\mathrm{A}} k_{f}\right)^{2}
$$

が成り立つ場合に発生する. $\mathrm{n}_{\mathrm{M}}, \mathrm{n}_{\mathrm{A}}$ が 1 4 の場合 について Table 2 にまとめられている. $18.4 \mathrm{meV}$ の 偽ピークは $\mathrm{n}_{\mathrm{M}}=2, \mathrm{n}_{\mathrm{A}}=3, E_{f}=14.7 \mathrm{meV}$ の場合である.

Table 2 Energy transfer of spurious peaks from higher order harmonics of monochromator and analyzer crystals. The values are normalized by $E_{f}$. The numbers in parentheses are the energy transfer in case of $E_{f}=14.7 \mathrm{meV}$.

\begin{tabular}{|l|l|l|l|l|}
\hline $\mathrm{n}_{\mathrm{M}}, \mathrm{n}_{\mathrm{A}}$ & 1 & 2 & 3 & 4 \\
\hline 1 & 0 & 3 & 8 & 15 \\
& & $(44.1)$ & $(117.6)$ & $(220.5)$ \\
\hline 2 & $-3 / 4$ & 0 & $5 / 4$ & 3 \\
& $(-11.0)$ & & $(18.4)$ & $(44.1)$ \\
\hline 3 & $-8 / 9$ & $-5 / 9$ & 0 & $7 / 9$ \\
& $(-13.1)$ & $(-8.2)$ & & $(11.4)$ \\
\hline
\end{tabular}

別な有名な例は，エネルギースキャンにみられ る不自然にシャープなピークである。これは，試 料からのブラッグピークをアナライザ結晶が非干 渉弾性散乱によりディテクタに散乱させてしまう 場合に発生する。一般に，非弾性散乱スペクトル はエネルギー方向にも波数方向にもブロードにな っているケースが多いので，観測されたピークが 分解能程度以下になっている場合には，このケー スを疑うべきである。

上記の 2 つケースは，固定エネルギーの変更 や， $E_{f}$ 固定を $E_{i}$ 固定に変えるなど，異なる実験条 件下で目的のピークが再現されるかどうかで判別 される，偽ピークの場合，実験条件を変えるとピ 一ク位置が変化するが，試料からのピークであれ ば実験条件に依存しない。

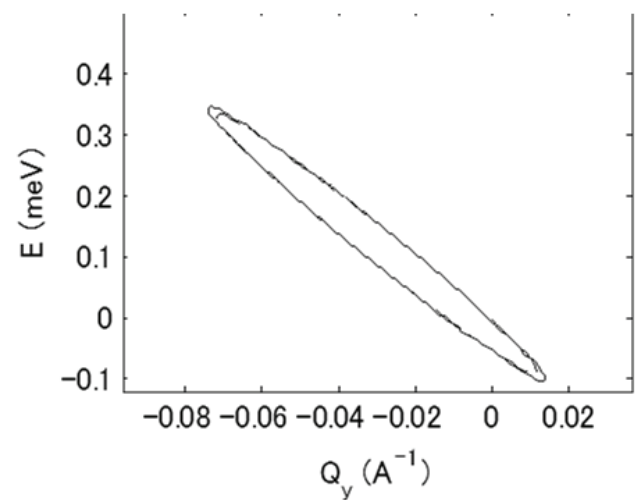

Fig. 8 Resolution function at $\left(\mathrm{E}, Q_{y}\right)=\left(0.1 \mathrm{meV},-0.03 \AA^{-1}\right)$ detecting Bragg peak at $Q_{y}=0$.

冷中性子の非弾性散乱で，低エネルギーに観測さ れる偽ピークとして, ブラッグピークの裾をひっか けてしまうケースがある. 分解能関数は一般に図の 
ように傾いている。もし $Q_{y}=0$ のところにブラッグ ピークが存在していると, $Q_{y}=-0.03 \mathrm{~A}^{-1}$ においてエネ ルギースキャンを行った場合に， $\hbar \omega \sim 0.1 \mathrm{meV}$ でブ ラッグピークの裾を観測することになる.

Fig. 9 のように, $\mathrm{q}=2.0 \AA^{-1}, \hbar \omega \sim 0.7 \mathrm{meV}$ 近傍にギ ヤップ的励起が観測された場合，それは液体ヘリ ウムのロトンスペクトルである可能性を疑うべき である。液体へリウムタイプのクライオスタット を使用していて，交換ガスとして $\mathrm{He}$ ガスを大量 に入れてしまった場合には，このようなスペクト ルを観測してしまう可能性がある。

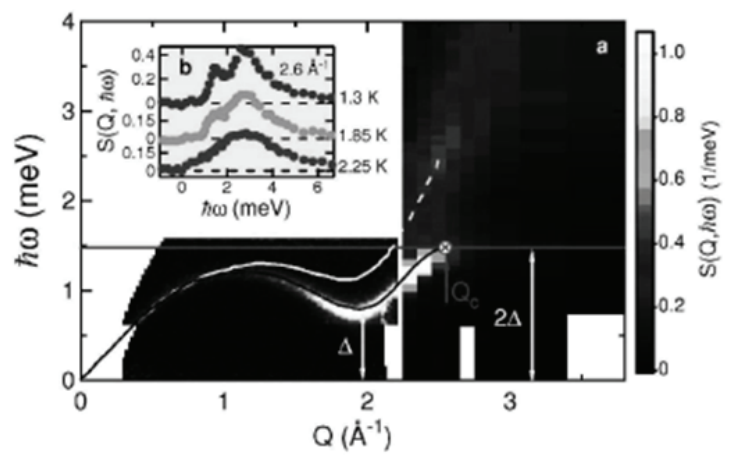

Fig. 9 Roton spectrum of Helium.

試料ホルダや試料缶は通常 $\mathrm{Al}$ を用いて作製し ているので, $\mathrm{Al}$ のブラッグピークには注意を払う ベきである. 中性子が照射されるアルミの量は, 可能な限り少量に抑えることが重要である。ただ し，磁場中での実験を行う場合には，トルクによ り試料が回転するケースがあるのでこの限りでは ない.

\section{(3) データ解析}

粉末試料実験で得られる情報は, 励起のエネル ギースケールと相関の強くなる波数（スカラー） のみである。したがって，粉末非弾性散乱実験の データのみで 1 本の学術論文をまとめることは, 一般的には，科学的に健全ではない。ただし，ス ピン・クラスター系 (0 次元) や 1 次元スピン系 の場合，粉末平均により失われる情報量が少ない ので，この限りではない.モデルとなる $\mathrm{S}(\mathrm{q}, \omega)$ を 粉末平均したものを, 実験データと比較すること で，詳細な議論が可能である。また，スピン・ギ ヤップの有無を議論する場合にも, 粉末非弾性散 乱実験は強力な手法である.

単結晶試料の場合, 実験データを，モデル計算 により得られる散乱断面積に分解能関数を畳み込 むことで得られる予想值を比較する. 分解能関数 畳み込みのソフトはフリーで公開されているので, それらを用いるとよい[13].

分解能関数は波数-エネルギー空間で形を変え るが, 限られたエネルギ一領域のデータ解析では, 分解能関数を不変と近似してデータ解析をする場 合がある。また，冷中性子実験のエネルギー領域 では，波数平面へ投影された分解能関数は円に近
い.このような場合，分解能関数のことを気にせ ず，観測されたピークの積分強度を散乱断面積と 近似してよい。散乱断面積から $\mathrm{S}(\mathrm{q}, \omega)$ を求める際 に，1 点気を付けるべきことがある. 散乱断面積 と $\mathrm{S}(\mathrm{q}, \omega)$ の間には,

$\frac{d^{2} \sigma}{d E d \Omega}=\frac{k_{f}}{k_{i}} S(\mathbf{q}, \omega)$

の関係式がある. 右辺に $k_{f} / k_{i}$ の因子がかけられて いるので, $d^{2} \sigma / d E d \Omega$ から $\mathrm{S}(\mathrm{q}, \omega)$ を求めるには 規格化が必要である.しかし, $E_{f}$ 固定の場合には, モノクロメータ下流に設置している中性子モニタ の感度が波数の逆数に比例しているため, $k_{f} / k_{i}$ 因 子を考慮する必要はない. $E_{f}$ 固定の実験では，モ 二タで計数された入射中性子数で規格化するので, 観測された中性子数はすでに $k_{f} / k_{i}$ が $\mathrm{S}(\mathrm{q}, \omega)$ にかけ られたものとなっているからである。

\section{5.まとめ}

中性子三軸分光器は, 粉末弾性散乱, 単結晶弾 性散乱，粉末非弾性散乱，単結晶非弾性散乱のい ずれもが可能な汎用性の高い分光器である. 分光 器のコアな部分へのユーザーアクセスが可能であ ることは，汎用性の高さにつながると同時に，中 性子散乱の初学者の教育にも適していることを意 味している.波数-エネルギー空間の任意の 1 点で の測定が可能であることと，定常的に中性子が結 晶に照射されていることから，非弾性散乱分光器 としては, 限定された波数-エネルギー領域での測 定で特に威力を発揮する。また，中性子偏極才プ ションを利用すれば，偏極中性子解析も可能であ る. 本稿では触れなかったが，水平集光のモノク ロメータやアナライザを設置することにより，こ こ 10 年で強度は格段に増大している.さらに海外 の施設では，多数の検出器を並べるマルチディテ クタシステムを用いることで，より効率的なデー 夕収集が可能な分光器 [14] も存在している.

J-PARC が本格稼働している現在, 非弾性用飛行時 間分光器や粉末回折計と相補的に利用することで, 物質科学の理解に貢献する重要な分光器となって いる.

謝辞

本稿の執筆にあたり，左右田稔氏から有益な助 言を頂いたことに感謝いたします。 
参考文献

[1] Y. Ijiri, T.C. Schulthess, J.A. Borchers, P.J. van der Zaag, and R.W. Erwin, Phys. Rev. Lett. 99, 147201 (2007).

[2] K. Kuwahara et al., Phys. Rev. Lett. 110, 216406 (2013).

[3] T. Nakano, M. Matsuura, A. Hanazawa, K. Hirota, and Y. Nozue, Phys. Rev. Lett. 109, 167208 (2012).

[4] Y. Tokunaga et al., Phys. Rev. Lett. 105, 257201 (2010).

[5] M. Soda et al., Phys. Rev. Lett. 106, 087201 (2011).

[6] 物性研で用いているアルミ製試料缶, 試料ホ ルダ等の情報は，物性研中性子施設のページに記 載されている。

http://www.issp.u-tokyo.ac.jp/labs/neutron/accesary/ac cinfo.html.

[7]筆者の研究室では, 高エネルギーX線ラウエ写 真装置を共同利用に提供している. $450 \mathrm{kV}$ 加速電 圧によりX線を発生させているため, 数 $\mathrm{cm}$ 程度 の厚みの金属化合物結晶であれば透過ラウエ写真 の撮影が可能である。

http://masuda.issp.u-tokyo.ac.jp/instruments.html

[8] Rietveld 解析のソフトとしては，泉富士夫氏の RIETAN や，ILLで開発されている FULLPROF な どが良く使われている。下記ページからソフトを 得ることができる.

http://fujioizumi.verse.jp/download/download.html http://www.ill.eu/sites/fullprof/

[9] A.S. Wills の開発した SARAh は Fullprofの入力 ファイルを自動生成してくれるので便利である. 下記ページからダウンロード可能である．

https://dl.dropboxusercontent.com/u/8933134/Website /Site/Welcome.html

[10] 各元素の（干渉性/非干渉性）散乱断面積, 散 乱長のデータベースは, 米国 NIST 研究所のホー ムページで公開されている.

http://www.ncnr.nist.gov/resources/n-lengths/

[11] M.J. Cooper and R. Nathans, Acta Cryst. 23, 357 (1967).

[12] Virspec はA. Zheludev が開発したソフトであ る.

http://www.neutron.ethz.ch/research/resources/virspec [13] ILLで開発された Rescal やZheludev 氏により 開発された Reslibが便利である.

[14] NIST の泠中性子マルチディテクタ分光器 MACS やILLの Flat cone などがある. 